\title{
AGRINECA
}

JURNAL ILMIAH AGRINECA

ISSN : 2721-074X (Online) - 2301-6698 (Print)

Available on : http://ejournal.utp.ac.id/index.php/AFP/index

This is Under CC BY SA Licence

\section{FAKTOR YANG MEMPENGARUHI MINAT KONSUMEN BERBELANJA BERAS ORGANIK DI SURAKARTA}

\section{FACTORS AFFECTING CONSUMER'S INTEREST FOR VEGETABLES IN SURAKARTA}

\author{
Ratih Dwi Kartikasari", Kusriani Prasetyowat, Suswadi \\ Prodi Agribisnis, Fakultas Pertanian, Universitas Tunas Pembangunan Surakarta \\ *E-mail : ratihkartika14@gmail.com
}

\begin{abstract}
The development of demand for organic products is largely due to the increased public awareness to consume food products that are low in chemical residues as part of the tendency for healthy lifestyles and return to nature. One of the most consumed from agricultural products by Indonesian people is rice. Consumer perceptions about products vary greatly, therefore marketers must pay attention to the needs and tastes of consumers in order to face competition. This study aims to know the level of interest of consumers in shopping for organic rice in Surakarta. The study was conducted in March 2019 in Surakarta City. The sampling technique used purposive sampling technique with a total of 30 respondents. Data analysis using Percentage of Excel and described descriptively. The results showed that health factors were the most important reason for consumers to consume organic rice with percentage of $91 \%$. The average level of interest of consumers in shopping for organic rice is high at $80 \%$. Therefore it is important for traders or producers to maintain and improve their performance so that consumers get satisfaction in shopping for organic rice.
\end{abstract}

Keywords: Consumer, organic, rice

ABSTRAK

Perkembangan permintaan akan produk organik banyak disebabkan oleh meningkatnya kesadaran masyarakat untuk mengkonsumsi produk pangan yang rendah residu bahan kimia sebagai bagian dari kecenderungan gaya hidup sehat dan kembali ke alam. Salah satu hasil pertanian yang paling banyak dikonsumsi oleh masyarakat Indonesia adalah beras. Persepsi konsumen tentang produk sangat bervariasi, oleh karenanya pemasar harus memperhatikan kebutuhan dan selera konsumen demi menghadapi persaingan. Penelitian ini bertujuan untuk mengethaui tingkat kepentingan konsumen dalam berbelanja beras organik di Surakarta. Penelitian dilaksanakan pada bulan Maret 2019 di Kota Surakarta. Teknik pengambilan sampel menggunakan teknik purposive sampling dengan total 30 resoponden. Analisis data menggunakan Prosentase Excel dan dijabarkan secara deskriptif. Hasil penelitian menunjukkan bahwa faktor kesehatan menjadi alasan paling penting bagi konsumen dalam mengkonsumsi beras organik dengan prosenatse sebesar $91 \%$. Rata-rata tingkat kepentingan konsumen dalam berbelanja beras organik tergolong tinggi yaitu $80 \%$. Oleh karena itu penting bagi pedagang atau produsen untuk menjaga dan meningkatkan kinerjanya sehingga konsumen memperoleh kepuasan dalam berbelanja beras organik.

Kata Kunci: Konsumen, Organik, Beras

PENDAHULUAN

Pertanian organik merupakan solusi atas perwujudan revolusi hijau yang digalakkan pada tahun 1960-an yang menyebabkan berkurangnya kesuburan tanah dan kerusakan lingkungan akibat 


\section{A GRINECA}

JURNAL ILMIAH AGRINECA

ISSN : 2721-074X (Online) - 2301-6698 (Print)

Available on : http://ejournal.utp.ac.id/index.php/AFP/index

This is Under CC BY SA Licence

\begin{tabular}{llcc}
\hline Skor untuk jawaban Sangat Penting & & Orang & Persen (\%) \\
\cline { 3 - 4 } $\begin{array}{l}\text { jawaban SP x 5 = A } \\
\text { Skoruntukjawaban Penting }\end{array}$ & $20-40$ & 9 & 30 \\
$\begin{array}{llc}\text { jawaban P x 4 = B } \\
\text { Tabel 1. Kriteria Tingkat Kepentingan Bauran }\end{array}$ & $41-60$ & 18 & 60 \\
Pemasaran & $>60$ & 3 & 10 \\
\hline
\end{tabular}

\begin{tabular}{cc}
\hline Nilai Tingkat & Keterangan \\
Kepentingan & Sangatrendah \\
\hline $0.00 \leq \mathrm{n} \leq 20,99$ & Rendah \\
$21.00 \leq \mathrm{n} \leq 40.00$ & Sedang \\
$41.00 \leq \mathrm{n} \leq 60,99$ & Tinggi \\
$61.00 \leq \mathrm{n} \leq 80,99$ & Sangattinggi \\
$81.00 \leq \mathrm{n} \leq 100$ &
\end{tabular}

Sumber :Sugiyono, 2012

Skor untuk jawaban Netral =

$\sum$ jawaban N x 3 = C

Skor untuk jawaban Tidak Penting =

$\sum$ jawaban TP x 2 = D

Sumber : Data Primer, 2019

Dari Tabel 2 dapat dilihat bahwa usia konsumen beras organik berkisar antara 20$>60$ tahun. Kelompok usia konsumen terbanyak terdapat digolongan usia 41-60 tahun. Pada golongan ini konsumen menyadari bahwa kesehatan merupakan hal yang sanagt penting untuk dijaga, dan menginginkan tubuh yang sehat di hari tuanya. Selain itu disebabkan karena kondisi fisik yang mulai melemah dan lebih sering terserang banyak penyakit sehingga golongan usia tua beralih mengkonsumsi makanan yang sehat serta dapat membantu menyembuhkan /mengurangi penyakit yang diderita. Pada golongan muda yaitu $20-40$ tahun banyak terdapat ibu hamil dan ibu muda. Seperti yang diketahui bahwa kandungan nutrisi yang terdapat pada beras merah sangat baik bila dikonsumsi ibu hamil dan anak-anak. Kelompok yang paling sedikit adalah usia $>60$ tahun, hal ini dikarenakan usia yang sudah tua dan masyarakat yang memperoleh serta menyerap informasi terkait produk pertanian organik belum sebanyak pada masyarakat usia produktif yang memiliki lingkup sosial lebih luas.

\section{HASIL DAN PEMBAHASAN}

\section{Karakteristik konsumen}

Berdasarkan hasil penelitian mengenai identitas konsumen yang meliputi usia, pendidikan, pendapatan rumah tangga, dan jumlah beras organik yang dikonsumsi maka dapat diperoleh informasi tentang karakteristik konsumen sebagai berikut.

a. Distribusi Frekuensi Usia

Tabel 2. Distribusi Frekuensi Usia Konsumen Beras Organik di Surakarta

Usia (th)
Jumlah

\section{b. Distribusi Frekuensi Pendidikan Terakhir}

Dari Tabel 3 diperlihatkan bahwa lama pendidikan konsumen berkisar antara 9 - 19 thn. Kelompok terbanyak berada pada pendidikan tinggi sarjana dengan prosentase sebesar 63,3\% yang disusul kelompok pendidikan pascasarjana sebesar $30 \%$, dan tingkat pendidikan SMA dengan prosentase $6,7 \%$. Hal ini menunjukkan 
JURNAL ILMIAH AGRINECA

ISSN : 2721-074X (Online) - 2301-6698 (Print)

Available on : http://ejournal.utp.ac.id/index.php/AFP/index

This is Under CC BY SA Licence

bahwa semakin tinggi pendidikan seseorang maka semakin banyak pula pengetahuan mereka termasuk tentang kandungan gizi, manfaat dari suatu makanan, serta semakin selektif pula mereka dalam menentukan dan memilih kualitas jenis makanan yang tepat untuk dikonsumsi oleh anggota keluarga. Keadaan ini sejalan dengan pendapat Sumarwan (2003) dimana konsumen yang memiliki tingkat pendidikan lebih baik akan sangat responsif terhadap informasi.

Tabel 3. Distribusi Frekuensi Pendidikan Terakhir Konsumen Beras Organik di Surakarta

\begin{tabular}{lcc}
\hline \multirow{2}{*}{$\begin{array}{c}\text { Pendidikan } \\
\text { Terakhir }\end{array}$} & \multicolumn{2}{c}{ Jumlah } \\
\cline { 2 - 3 } & Orang & Persen (\%) \\
\hline SMA & 2 & 6,7 \\
S1 & 19 & 63,3 \\
S2 & 9 & 30 \\
Total & $\mathbf{3 0}$ & $\mathbf{1 0 0}$ \\
\hline
\end{tabular}

Sumber : Data primer, 2019

Tabel 4. Distribusi Frekuensi Pendapatan Rumah Tangga Konsumen Beras Organik di Surakarta

\begin{tabular}{|c|c|c|}
\hline \multirow{2}{*}{$\begin{array}{c}\text { Pendapatan } \\
\text { rumah tangga }\end{array}$} & \multicolumn{2}{|c|}{ Jumlah } \\
\hline & Orang & Persen (\%) \\
\hline$<\operatorname{Rp} 1.000 .000$ & 0 & \\
\hline $\begin{array}{l}\operatorname{Rp} 1.000 .000 \text { s.d } \\
\operatorname{Rp} 2.999 .999\end{array}$ & 8 & 26,7 \\
\hline $\begin{array}{l}\text { Rp 3.000.000 s.d } \\
\text { Rp 4.999.999 }\end{array}$ & 15 & 50 \\
\hline$>\operatorname{Rp} 5.000 .000$ & 7 & 23,3 \\
\hline Total & 30 & 100 \\
\hline
\end{tabular}

Sumber : Data Primer, 2019

c. Distribusi Frekuensi Pendapatan Rumah Tangga

Dari Tabel 4 dapat dilihat bahwa pendapatan konsumen berkisar antara $\mathrm{Rp}$ 1.000.000 sampai dengan lebih dari $\mathrm{Rp}$ 5.000.000. Kelompok terbanyak berada pada pendapatanRp 3.000 .000 sampai dengan lebih dari Rp 4.999.999 dengan prosentase sebesar 50\%, yang disusul kelompok pendapatan Rp 1.000 .000 s.d Rp 2.999.999 dengan prosentase 26,7\%, dan terakhir adalah kelompok pendapatan $>$ Rp 5.000.000 sebesar 23,3\%. Masyarakat pada umumnya mengasumsikan bahwa beras organik hanya dikonsumsi oleh keluarga yang berpendapatan tinggi, tetapi dari data hasil penelitian pada Tabel 3 diatas terlihat bahwa, beras organik juga banyak dikonsumsi keluarga dengan pendapatan menengah.

\section{d. Distribusi Frekuensi Jumlah Beras Organik yang Dikonsumsi}

Dari Tabel 5 diatas dapat dilihat bahwa jumlah beras organik yang dikonsumsi berkisar antara <5 - >10 kg. Kelompok terbanyak berada pada konsumsi beras 5-10 kg per bulan yang disusul kelompok konsumsi konsumsi $<5 \mathrm{~kg}$ dan $>10 \mathrm{~kg}$ dengan prosentase 30\%.Salah satu faktor yang mempengaruhi jumlah konsumsi beras organik adalah jumlah tanggungan rumah tangga yang berbanding lurus terhadap jumlah beras organik yang dikonsumsi. Semakin sedikit jumlah anggota keluarga, semakin sedikit beras yang dikonsumsi.

e. Faktor yang Mempengaruhi Minat Beli Konsumen Beras Organik

Analisis tingkat pentingnya bauran pemasaran diperoleh dari jawaban responden untuk setiap pertanyaan pada masing-masing

Tabel 5. Distribusi Jumlah Beras Organik yang dikonsumsi per bulan

\begin{tabular}{lcc}
\hline $\begin{array}{c}\text { Jumlah Beras } \\
\text { Organik }\end{array}$ & \multicolumn{2}{c}{ Jumlah } \\
\cline { 2 - 3 } & Orang & $\begin{array}{c}\text { Persen } \\
(\%)\end{array}$ \\
\hline$<5 \mathrm{~kg}$ & 9 & 30 \\
\hline
\end{tabular}


JURNAL ILMIAH AGRINECA

ISSN : 2721-074X (Online) - 2301-6698 (Print)

Available on : http://ejournal.utp.ac.id/index.php/AFP/index

This is Under CC BY SA Licence

\begin{tabular}{lcc}
\hline $5-10 \mathrm{~kg}$ & 12 & 40 \\
$>10 \mathrm{~kg}$ & 9 & 30 \\
Total & $\mathbf{3 0}$ & $\mathbf{1 0 0}$ \\
\hline
\end{tabular}

Sumber : Data Primer, 2019

Atribut yang telah ditetapkan. Jawaban yang diperoleh dianalisis secara deskriptif dengan tujuan untuk memperoleh gambaran mengenai masing-masing item pertanyaan serta rata-rata setiap atribut.Analisis deskriptif selengkapnya disajikan dalam rekapitulasi hasil jawaban responden untuk masing-masing pertanyaan yang diperoleh dari hasil penyebaran kuesioner sebagai berikut :

Tabel 6. PencapaianSkorTingkat Pentingnya Faktor Responden Terhadap Minat Beli Beras Organik di Surakarta

\begin{tabular}{|c|c|c|}
\hline $\begin{array}{l}\text { Indikator } \\
\text { Bauran } \\
\text { Pemasaran }\end{array}$ & $\begin{array}{c}\text { Tingkat } \\
\text { kepenting } \\
\text { an }(\%) \\
\end{array}$ & Kategori \\
\hline Kepulenan nasi & 79 & Tinggi \\
\hline Aroma nasi & 82 & $\begin{array}{l}\text { Sangat } \\
\text { Tinggi }\end{array}$ \\
\hline Daya tahan nasi & 87 & $\begin{array}{c}\text { Sangat } \\
\text { tinggi }\end{array}$ \\
\hline $\begin{array}{l}\text { Bersih dari } \\
\text { benda asing }\end{array}$ & 86 & $\begin{array}{l}\text { Sangat } \\
\text { tinggi }\end{array}$ \\
\hline $\begin{array}{ll}\text { Daya } & \text { tahan } \\
\text { beras } & \text { untuk } \\
\text { disimpan } & \end{array}$ & 87 & $\begin{array}{l}\text { Sangat } \\
\text { tinggi }\end{array}$ \\
\hline Kemasan beras & 60 & Sedang \\
\hline Nutrisi & 91 & $\begin{array}{l}\text { Sangat } \\
\text { Tinggi }\end{array}$ \\
\hline Promosi beras & 83 & $\begin{array}{l}\text { Sangat } \\
\text { Tinggi }\end{array}$ \\
\hline Harga beras & 57 & Sedang \\
\hline $\begin{array}{l}\text { Pemberian } \\
\text { informasi oleh } \\
\text { pedagang }\end{array}$ & 83 & $\begin{array}{l}\text { Sangat } \\
\text { tinggi }\end{array}$ \\
\hline $\begin{array}{l}\text { Kemudahan } \\
\text { memperoleh } \\
\text { beras }\end{array}$ & 85 & $\begin{array}{l}\text { Sangat } \\
\text { tinggi }\end{array}$ \\
\hline Rata-rata & 80 & Tinggi \\
\hline
\end{tabular}

Sumber : Data Primer, 2019
Konsumen memiliki preferensi yang berbeda terhadap keputusan dalam pembelian beras organik. Preferensi konsumen dapat dilihat dari bauran pemasaran yang nampak pada beras organik. Dari hasil survey, diketahui bahwa konsumen memiliki perhatian besar terhadap kandungan gizi atau nutrisi pada beras dengan prosentase tingkat kepentingan sebesar 91\%. Beras organik dikenal sebagai produk makanan pokok yang lebih sehat dibandingkan dengan beras non organik. Alasan kesehatan ini telah menjadikan hasil pertanian ramah lingkungan seperti pertanian organik untuk semakin diminati. Makanan organik lebih bergizi dan sehat karena tidak dibentuk menggunkaan pupuk kimia, pestisida kimia serta bahan kimia lain, sehingga tidak merugikan tubuh manusia. (Ide, 2014). Berdasarkan hasil penelitian beras organik memiliki kandungan proteiin $8 \%$, lebih tinggi $1 \%$ dibandingkan beras biasa dan $1,5 \%$ lemak nabati (Purwasasmita dan Sutaryat, 2014). Penelitian Waryat dan Handayani (2017) memaparkan bahwa beras organik lebih unggul dari beras non organik karena memiliki nutrisi dan mineral yang tinggi, kandungan glukosa, karbohidrat dan protein yang mudah terurai sehingga aman dan sangat baik untuk dikonsumsi.

Tingkat kepentingan yang kedua menurut konsumen terhadap beras organik adalah daya tahan beras untuk disimpan dan daya tahan nasi setelah dimasak yaitu sebesar $87 \%$. Beras organik pada dasaranya memiliki daya simpan yang lebih rendah bila tidak dengan perlakuan yang tepat, hal ini dikarenakan beras organik lebih mudah berkutu daripada beras non-organik akibat tidak diberi pestisida kimia dalam masa budidaya. Sehingga kutu memilih beras organik yang tidak membahayakan baginya. Beras organik yang berkutu bukan karena beras organik yang sudah lama atau sudah 
